\title{
Study on Teaching Reform of the Swine Production Course
}

\author{
Yongshun Che ${ }^{1, a}$ \\ ${ }^{1}$ College of Animal Science and Technology, Jilin Agricultural University, Changchun 130118, \\ China \\ aemail: cheyongshun@163.com
}

Keywords: Swine production; applied undergraduate; skill training; teaching reform

\begin{abstract}
The swine production "is one of animal science specialty practice strong backbone of the professional courses, under the situation of the transformation of applied type undergraduate teaching, reform the teaching method, means and methods of assessment is improve teaching effect of the course, to skilled personnel training goal and objective requirements. Through analysis of swine production enterprise talent and ability requirements, proposed the principle "swines" skilled and applied talents training objectives, and to explore the path of reform teaching methods and assessment methods, to basic knowledge, basic skills and expand capacity three levels of personnel training objectives. "Science" curriculum reform of swine production will not only help to improve the teaching level, but also for animal science and other professional courses with the promotion of significance.
\end{abstract}

\section{Introduction}

China is the largest country in the world, and it plays a very important role in animal husbandry and people's lives. In recent twenty years, with the rapid development of China's swine industry, has from the family scattered to support the development of scale, industrialization and market-oriented mode of farming, so to the enterprise transport application type, innovative, skilled personnel in swine become the chief target of personnel training in Colleges and universities. Swine production is a practical and highly applied professional course for the specialty of animal science. Therefore, as one of the main courses of Animal Science Specialty "swines", there are also adapt to the needs of the teaching reform of higher education marketization and application skills of swine production, that is, to cultivate master swine production, construction, management, operation and service to first-line applied specialized personnel of the objective demand. For application-oriented talent training direction of the swine production "teaching and practice reform should be to expand the students knowledge structure and level, emphasize the cultivation of swine production, the practical application of skills, such as the advanced philosophy of macroscopical and decision-making ability, safety and efficient production, market operation and management, improve students in swine industry prenatal, delivery and postnatal production technology of ability of operation. It is more important to reform and promote the development of swine industry in other main courses of animal science, and it also has great significance to the development of swine production.

\section{"Swine production" teaching problems}

"The basic theory" course and concise swine production operation is extremely strong, and "animal genetic breeding", "animal breeding science", "animal nutrition", "feed", "livestock products processing", "veterinary medicine" and other professional courses are closely related, involving swine breeding, biology the characteristics of modern swine, each link and the production management technology of [6 - 7]. However, swine production is becoming more intensive, swine infectious disease complicated by the development of the course teaching has following problems: to highlight the pure theoretical teaching and ignore or no conditions of practical skills training, which makes students lack of learning interest; swine technology science teaching, only focusing on 
each link swine production process, the lack of systematic knowledge through experiment and practice; the content is simple, most of experiment and study of learning, students can really participate in specific processes and links to the actual demand of swine production in swine production and the status quo, the practical ability of students to get training and training, but also help the cultivation of students' comprehensive quality and innovative consciousness of $[[3,10]$. Therefore, in the Ministry of education to the cultivation of application-oriented personnel under the trend of reform, in order to improve the training effect of "skill of animal science specialty people" teaching reform is imperative in swine production.

\section{The principles of the teaching reform}

"Swine production" is a theory and practice of closely related courses, to guide actual production, focus on skills training and contact theory is the basic course and characteristics. With the change of the training pattern of applied talents, in the organization of "swine production" teaching should focus on training, "(administrator) basic talents and technology talents (technicians, breeders, epidemic prevention staff) and management personnel (production director)" of the curriculum goal of the personnel training, construction of basic knowledge basic skills (technician, breeders), the ability to expand (production director) "curriculum system. Therefore "swine production" teaching reform should be through continuous reform and renewal theory teaching content, to the production of the post demand as the guidance, highlight the practical application of skills, enhance training, improve the students' ability to make comprehensive use of theoretical knowledge and practical skills, stimulate the students' active learning curriculum passion.

\section{The measures of teaching reform}

According to the market demand for the application of animal science talents, develop "swine production" teaching objectives and teaching content, including teaching contents will be divided into the basic knowledge, basic skills and ability to expand, develop knowledge and learning requirements; curriculum in multimedia teaching, scene teaching, on-site examination and comment on students' learning; design single target (basic knowledge, skills, ability level display or assessment) in three aspects.

The teaching content to large-scale farms in the actual post demand as the goal, to cultivate students' comprehensive skills and operation as the starting point of the design of teaching activities. Therefore "swine production" curriculum reform needs to break the original theory and practice of light teaching system through the boar breeding and production, sow raising management, swinelets, fattening swine production, reserve production breeder breeding boars management technician, semen breeding, feeding and management of sows and swinelets, swine reserve technician and the swine production technician, technicians, technical director, production technology of swine fattening epidemic prevention controller post 5 main links needed in the technology innovation framework of theoretical knowledge and practical skills, so the combination of theory and practice, practice base of making full use of inside and outside, and the scene of developing multimedia teaching mode, teaching methods of creating ability the driver, in order to cultivate comprehensive application, have qualified for the modern swine farm technology personnel occupation ability of skilled personnel .

Establish and improve the basic knowledge, basic skills and ability to expand a student as a standard assessment system, to reform the traditional paper examination oriented evaluation system, increase skills training practice and training achievement assessment scale, the corresponding reduction theory test scores in the proportion of the total learning assessment, so as to objectively evaluate students' knowledge and mastering of skills, and actively guide students to strengthen the theory with practice, pay attention to training and exercise skills in production practice.

In order to change the traditional theory of test scores with grade of test report as performance appraisal courses, therefore in the examination of curriculum theory at the same time, strengthen and highlight the practical skills assessment, it must master the 5 skills of at least 2 in the 
production process according to the students' interest, and for each one of the specific skills required characteristics. Formulate the standard for evaluation in detail, which can objectively reflect the degree of mastering the skills of the students, and comprehensive evaluation on operating skills from the production practice of raising technology related theory questions, questions and hands-on ability, or failure and repair.

The application of modern multimedia network technology. The application of modern multimedia technology, can provide more intuitive animal production technology theory and production practice knowledge for students. The theory of the teaching content of the multimedia information has been completed, classroom use slides and video combination. The establishment of teaching website of pig production course in quality course construction work, the teaching materials related curriculum, including teaching syllabus, teaching materials, teaching courseware and electronic lesson plans, teaching video, video teaching, expert lectures, questions over the years, to achieve all of the Internet, convenient for students to download query. On the course website has a student voicemail. Still portal website built on the course of micro-blog. Students and teachers can achieve in the interaction of the students before and after the network teaching information platform construction fast and smooth.

The case teaching of the case facts are analyzed and the bridge between the construction of classroom teaching and field operation, theoretical knowledge and practical production. Students in the case, actively explore the effective information shows that the cognitive conclusion form decision. Specific steps include: according to the curriculum requirements and the reality of students, the teacher in the class before the selection of typical cases, develop discussion questions and requirements. In the classroom teaching, teachers by means of multimedia and the Internet display case background and details of the process and appropriate analysis; students' Thinking on the case facts, and discussed according to the different argument group; teachers timely guide the focus of discussion, revealing the differences and connections between the various points of the theory, and summarizes the. After class, the students continue to discuss the case, and wrote the book and independent case analysis materials.

\section{Conclusion}

Establish and improve the basic knowledge, basic skills and ability to expand a student as a standard assessment system, to reform the traditional paper examination oriented evaluation system, increase skills training practice and training achievement assessment scale, the corresponding reduction theory test scores in the proportion of the total learning assessment, so as to objectively evaluate students' knowledge and mastering of skills, and actively guide students to strengthen the theory with practice, pay attention to training and exercise skills in production practice.

In order to change the traditional theory of test scores with grade of test report as performance appraisal courses, therefore in the examination of curriculum theory at the same time, strengthen and highlight the practical skills assessment, it must master the 5 skills of at least 2 in the production process according to the students' interest, and for each one of the specific skills required characteristics. Formulate the standard for evaluation in detail, which can objectively reflect the degree of mastering the skills of the students, and comprehensive evaluation on operating skills from the production practice of raising technology related theory questions, questions and hands-on ability, or failure and repair.

Through the teaching practice to carry out specific work of production in various forms, improve the students' practical ability is the main way to implement the basic way and skill teaching practice aim. Teachers can use the "production and learning, combining the school enterprise docking" method, select the province surrounding well-known large-scale pig farming enterprises, cooperation and business negotiation, the establishment of College Students' scientific research base, will be part of the learning content on the practice base. In the base period, students with the formal employees of the enterprise's identity, according to the work arrangement, the use of knowledge and skills for business services. After a period of teaching practice, students can not only master the practical operation to consolidate the theoretical knowledge, and reinforcement learning, a sense of 
crisis and urgency, to improve the competitive consciousness and service consciousness of employment. Students by participating in the actual production of farming enterprises, improve the ability to work independently and effectively overcome the disadvantages of traditional agricultural college professional education theory from reality. The students basically grasp the whole process of pig production techniques, to enter the job after graduation to shorten.

\section{References}

[1] Pang W J, Sun S D, Yang G S. Study on Teaching Reform of the Swine Production Course[J]. Journal of Animal Science \& Veterinary Medicine, 2013.

[2] Ding Y, Zhang C H, Zhang X D, et al. Assumption of Teaching Reform of The Swine Production Course for Animal Science Major[J]. Animal Husbandry \& Feed Science, 2010.

[3] Zhang JJ, Sheng-Zhong L I, Zhai X R, et al. Teaching Reform of Freshwater Aquaculture Co2urse for Animal Science Major[J]. Animal Husbandry \& Feed Science, 2014.

[4] Joksimovic'-Todorovic' M, Hristov S, Davidovic' V. Behaviour of sows and swines in a course of the lactation period.[J]. Macedonian Journal of Animal Science, 2011.

[5] Zaleski H M. Integrating Teaching and Extension: Swine Production[C]// American Society of Animal Science Joint Annual Meeting. 2014. 